\title{
Püao-te-Āta-tü: Informing Māori social work since 1986
}

\author{
Awhina Hollis-English
}

Dr Awhina Hollis-English is of Ngäti Porou, Whakatohea, Te Whänau-a-Apanui and Kahungunu ki Wairoa descent. She is a lecturer at Massey University in Palmerston North and teaches into a range of papers from social work to policy research and evaluation. Awhina has close links to Taharora Marae at Waipiro Bay and grew up in Hawkes Bay.

\section{Abstract}

The Püao-te- $\ddot{t}$ ta-tü Report (1986) is the founding document of Mäori social work in Aotearoa, second only to Te Tiriti o Waitangi (1840) in its significance for Mäori social workers. This article presents the influences of Püao-te- $\ddot{A}$ ta-tü over the past 20+ years on Mäori social work. The Report promoted significant changes to social work; in particular, the development of social work practices by Mäori, with whänau Mäori. In light of its significant nature, research was undertaken with eight Mäori social workers to engage them in discussion on the influential nature of Püao-te- ̈̈ta-tü on their social work practice. This article presents the participants' comments, and emphasises the impact Püao-te-Äta-tü had on Mäori social work practice methods (Hollis, 2006).

\section{Introduction}

When I was a young and enthusiastic social work student, one of the messages I picked up along the way was that the Püao-te-Äta-tü Report (1986) was instrumental in shaping Mäori social work. However, a conflicting message that resonated with me at the time was its lack of implementation, acknowledgement or even awareness by many social workers in Aotearoa New Zealand. The similarity between this and the Treaty of Waitangi (1840) shocked me as I was about to launch into my own career as a Mäori social worker. Unsurprisingly I focused my postgraduate research on Püao-te-Äta-tü and the implications for Mäori social work practice. This article draws heavily on this research and presents the views of Mäori social workers in order to develop an understanding of the true impact of the Report on their practice methods since the 1980s. Eight Mäori social workers from various organisations participated in this research. The findings show that while the Püao-te-Äta-tü Report was instrumental in changing the social service environment and some elements of practice, rather than changing Mäori practices, it validated the use of tikanga in the social services (Hollis, 2006). Of particular importance is the high level of support Mäori social workers have for the Report, even though their colleagues have not similarly embraced it.

\section{Research background and literature}

This research has a dual focus. At a structural level, the Püao-te-Äta-tü Report has been selected because it was the first official government document that acknowledged Mäori social work methods and recommended their use. It validated the Treaty of Waitangi and 
sought an end to racism within the Department of Social Welfare (Keenan, 1995). In his discussion of some of the exciting and the frustrating aspects of the Püao-te-Äta-tü journey, Walker describes its importance:

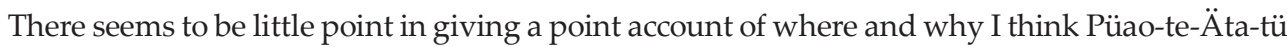
has been assigned to the back-water. The important thing is Mäori have not and will not forget it. It is truly a policy document of the people. It will not go away (Walker, 1995).

The Report's influence on Mäori social work development has been at both an organisational (meso) level and an individual (micro) level. This encompasses both the use of traditional Mäori practices by workers and by organisations, as well as the introduction of contemporary models. Around the time the Püao-te- ̈̈ta-tü was introduced, social work models developed out of a general recognition that there was an absence of procedures and forums that encouraged whänau and their communities to support each other through state services (Pitama, 2003). Thus, Mäori social workers and academics developed models and 'best practices', blending ancient and modern Mäori knowledge into coherent narratives (Hemara, 2000). Traditional Mäori belief systems provide the foundation of a Mäori paradigm in a contemporary setting as well as in classical times (Hakiaha, 1997).

\section{Research methods and methodology}

This project was guided by Constructivism and Kaupapa Mäori theory. Constructivist theory is a process in which one's interpretation of the world is constructed through interactions and transmitted throughout society (Bruner, 1990; Crotty, 1998; Huitt, 2003; Mahoney, 2004). Similarly, Kaupapa Mäori theory is an ever-evolving praxis that developed out of Mäori communities as a way of interpreting, resisting and transforming the negative results of colonisation. It is a theory of change that focuses on Mäori having the power and control over research and other interactions with Mäori, such as in social work practice (Bishop, 1996; Smith, 1999; Kiro, 2000; Glover, 2002; Smith, 2003; Walsh-Tapiata, 2003; Walker, 2005).

Qualitative and Kaupapa Mäori research methods guided the research process and acted as a 'code of conduct' for myself as a Mäori researcher (Bevan-Brown, 1998; Smith, 1999; Eketone, 2008). Ruwhiu (2001) states that tikanga could be described as the legal system in which all dealings within Mäoridom operate. Tikanga is the overarching protection or the cultural paradigm in which researchers, social workers, or anyone who identifies with Kaupapa Mäori should function.

The principle of tuakana-teina has been described as paramount when researching within a Mäori context. This gives the participant the status of the Tuakana/elder sibling, acknowledging their role as the 'expert and classifier' and values their knowledge as tapu (Walker, 2004). As a researcher, I chose to take the role of the mokopuna, where the participants are the kaumatua. Through labelling myself as a mokopuna as opposed to the teina I am acknowledging my age and social work experiences. I chose this stance for this particular project because it adequately reflects the status, long-term experience and knowledge of the research participants. The knowledge contained in this article is not a commodity; its ownership will always be with the participants for the benefit of Mäori social work and whänau Mäori.

Interviews were held with Mäori social workers that are currently working in a social service organisation and have done so since the 1980s. Their roles differ and in many cases have changed over the years. They vary from having once been a client themselves, to 
having foster children living in their homes. They have also been social workers at CYF, in mental health settings, at hospitals and in Mäori, iwi and community-based organisations. Participants were cultural advisors, lecturers, played significant roles in the establishment of Kura Kaupapa and Köhanga reo, and in some cases, were on the trust boards of social services. Following a whakawhanaungatanga process, the participants were asked openended questions about the Püao-te-Äta-tü Report as well as its influence on their social work practice. Their körero are presented here and reflect the significant themes from the interviews. These themes have been presented in two groups, first the themes that relate to the 'micro' or social work practice methods, and second those that relate to the 'meso' or organisational changes. The themes are: traditional Mäori concepts and practices, surrounding influences on Mäori methods of practice, changing methods for working with Mäori whänau, improving support for Mäori social work methods, changing social service organisations, and struggles that arose during the changes.

\section{Traditional Mäori concepts and practices}

The majority of participants responded that the first practices they used when working with Mäori clients in particular, but also non-Mäori clients, were the rituals of encounter, whakapapa and whakawhänaungatanga. 'When you are working with our people you need to go with whakawhänaungatanga first. You are getting to know them as a person, not getting to know their troubles straight away'. Mäori social workers need to know their own whakapapa and knowledge of the community in order to develop whakawhanaunatanga with whänau. 'It's about how you identify, you have to know your whakapapa ... each of us brings with us our tüpuna'. However, participants acknowledged that due to colonisation and urbanisation many Mäori have lost the ability to make these connections.

A second theme that emerged from the interviews was the notion of aroha, compassion, respect or empathy. This context has been described in two ways, the first being a reciprocal respect given to colleagues and whänau without discrimination. The second is described here: 'when our old Mäori people came into the office, they were spoken to in Mäori. They were taken aside and recognised for who they were'. This form of respect or compassion requires additional skills and processes that take into consideration age, status and situation. The use and fluency of Te Reo Mäori was fundamental to all Mäori social workers interviewed and was described in different ways. There was a general agreement that knowledge of Te Reo Mäori was vital for the understanding of tikanga Mäori and when working with Mäori people, the greater one's knowledge of the reo is the better they are at incorporating tikanga into their practice.

Participants stated that the concept of kanohi-ki-te-kanohi is about giving the client respect by going to them, being there in person and hearing their side of the story. This is done without making assumptions or false conclusions. As a whole, participants agreed that the methods they use draw on traditional Mäori practices and reflect a Mäori worldview: 'At the time, we did not use te whare tapa whä or te wheke ... because those models were not written. They were still the dreams in the minds of guys like Mason Durie. So you would just draw on what you thought were Mäori ways to view the world'. Participants agreed that contemporary Mäori models of practice are greatly needed and each participant supported theorists and writers on Mäori models. It was also noted that no participant claimed to use a contemporary model: rather, they described the use of tikanga and traditional practices as being of primary use in their everyday practice. 


\section{Surrounding influences on Mäori methods of practice}

One area that was significantly influential to participants' practice methods was the positive influence of a kuia or kaumätua who guided their learning and inspired them to develop their knowledge and use of tikanga Mäori. As a young social worker, support from their elders was fundamental to the participants' development of their Mäoritanga and as social workers. One participant stated: 'I was strongly influenced by my own kaumätua ... That's how I was brought up so it was easy for me to rapport with them, be in their korowai'. Another participant described how he worked with a kuia who was like a mentor to him. He described how spending time with her was actually a fundamental time of learning where he gained knowledge of Mäori issues and the history of the area in which they lived. One participant said: 'I was 'buddied' up to a kuia and we utilised a number of community linkages, connecting with other kuia and koroua ... so that was quite influential for me to be working alongside a kuia who came with a lot of traditional knowledge that she brought from the haukainga'. The majority of participants also spoke of how these kaumätua developed into long-term mentors and played significant roles in their learning. Another participant commented: 'I have endeavoured to listen to their counsel because they have been critical in my own growth'.

A second, and just as significant factor to influence Mäori practice methods, was the changing political climate of the 1980s. There was a growing awareness that in order to better support whänau Mäori, organisations needed to implement Mäori approaches. Around

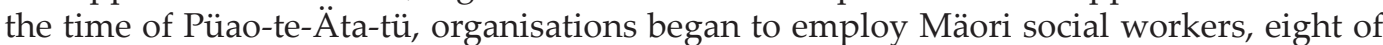
which were the participants in this research. While the participants were employed before the report, it was not until after the report that Mäori methods of practice were encouraged. One participant stated: 'Looking back to the 1980s when Püao-te-Äta-tü came into being, the environment was becoming really political in relation to services towards Mäori'. Participants stated that they could now use Mäori practice methods, while these had not yet been 'defined', but they could do so freely without 'getting into trouble' and no longer needed to 'break the rules'.

\section{Changing methods for working with Mäori whänau}

There was an overall consensus that the principles behind Mäori social work methods of practice have not changed in the last 20 years. Processes such as whanaungatanga and whakapapa remain the same for Mäori social workers and have not changed greatly over time. If anything, the way tikanga processes are used within the social services have been

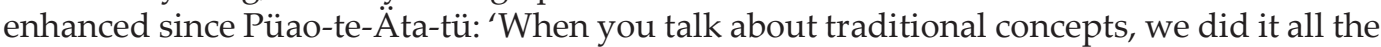
time, whanaungatanga, that's how we work. We haven't changed our way of working, it has just rubbed off on the other staff'. There was a general feeling that although they might not have known the 'labels' for what they were doing, methods have fundamentally stayed the same. One participant stated that after Püao-te-Äta-tü social workers could treat elders with the respect and dignity they deserve without 'getting a rap on the knuckles for taking an hour to talk to someone'. Therefore, one's use of this method has increased as a result of its acceptance, and some participants would argue that they haven't changed - they have just been enhanced and refined.

Participants agreed that the use of whakapapa connections has been consistently an important aspect of Mäori social work throughout time and a vital aspect of this is knowing one's own whänau, hapü and iwi. One participant said: 'well if you don't know where you are from and what you are doing then you can't deliver that to our people'. Püao-te-Äta- 
tü validated and encouraged the acceptance of Mäori family types, parenting styles and practices. Many participants agreed that one of the more practical changes after the Report was the acknowledgement of whänau, hapü and iwi into the 1989 Children, Young Persons and their Families Act (CYPF Act).

\section{Improving support for Mäori social work methods}

One of the significant changes that happened as a result of the Püao-te-Äta-tü Report was the beginnings of support for Mäori social work methods within the Department: 'with the introduction of Püao-te- ̈̈ta-tü that is when things really changed ... the Ministry started having to realise that there was more to dealing with people than their way'. The predominant theme in this section of the interviews was that the Report created huge changes for Mäori social workers, in terms of their identity and their practice. Not only were organisations actively employing Mäori but their methods were also being validated, which encourages the acceptance and understanding of Mäori ways of doing things.

The notion of being validated in one's practice was important to participants: 'It broke the barrier for me, all of a sudden I felt good about being Mäori. When Püao-te-Äta-tü came out, one participant was ecstatic because the report stated 'our way of doing things is professional and it is no longer second best. It felt really good to be considered an expert in your own arena'. Therefore, the Report promoted the normalisation of being Mäori and a social worker.

The overall view that positive change was to come out of this report meant that participants recognised Püao-te-Äta-tü as being responsible for new initiatives that benefited Mäori whänau, clients and workers. One participant added that they were able to provide culturally appropriate settings for their work to take place, rather than the same 'Päkehä' setting 'I'm not saying it's right or wrong, I'm just saying that in a Mäori world, that is where they can identify'. So the possibilities were open for Mäori social workers to use Mäori methods and develop them in a way that Mäori whänau could relate to and felt comfortable in.

One participant commented that following Püao-te-Äta-tü social service organisations started to recognise people's ability to körero Mäori. The use of powhiri or mihi whakatau was introduced in the workplace and enabled Mäori social workers to welcome new staff to the job but also impact upon the cultural environment of the office. 'After Püao-te- Äta-tü came out that is when we started having formal welcomes ... and they started calling on the expertise within the staff to whaikorero'. Participants stated the introduction of a pöwhiri meant that Mäori methods were being acknowledged and accepted.

One of the major implementations at the time was the establishment of Mäori teams within social service organisations. Through these teams, in some organisations called 'Roopu teams' they were able to gain support from each other in the development and enhancement of their Mäori methods and to support each other through difficult times. This system functioned successfully when Mäori managers and supervisors were also employed to support and maintain the groups.

\section{Changing social service organisations}

As previously stated, social service organisations before Püao-te-Äta-tü came out were fundamentally monocultural. One participant said: 'I started in the 1970s and it was just a 
real Päkehä world ... there really wasn't any notice taken of other people's customs, not just Mäori, everyone was treated the same'. Participants said that there were very few Mäori social workers and in certain parts of the country there were no Mäori social workers. Instead, social workers were predominantly 'white, middle class' and lived outside of the communities of the families they worked with.

Others commented that they were forced to suppress their 'Mäoriness' and assimilate into the mainstream system: 'Before Püao-te-Äta-tü you did whanaungatanga but not a great deal, it was a sterile environment'. One participant said that he always used Mäori methods with Mäori and non-Mäori clients but chose not to tell anyone what he was doing. Therefore, the changing political climate meant that participants could use methods that came naturally to them, as opposed to repressing or disguising their Mäori processes.

Participants stated that the processes of dealing with children and young people before Püao-te-Äta-tü were alien compared to traditional Mäori concepts of whakapapa and kanohi-ki-te-kanohi. They stated that within social services there was a perception that policy makers were founding their policies upon western theories rather than considering what the Mäori community wanted. This included a feeling that policy makers were assuming what 'a Mäori' was like and were not taking a Mäori perspective or regional issues into account. 'One thing that was really noticeable was that if you were a 'white'-looking person you were classed as Päkehä. They didn't realise that a lot of those white-looking people were actually Mäori'. Before Püao-te-Äta-tü was released it seemed that policy makers were judging what it was to be Mäori based on their views of a minority group of Mäori representatives, such as government officials. Participants said that the people advising policy makers were perhaps too detached from the real needs of the community and that the target group was not actually being reached.

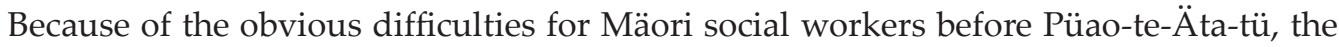
majority of participants felt a strong sense of 'us and them'. One participant said: 'at the same time there was a real underground 'us and them' thing. There was the department and then there was us'. There were other versions of 'us and them'; in some cases it was 'us and management' and in others cases it was 'us and government' and in many cases it was regarding 'Mäori and non-Mäori'. Generally there was mistrust of western theories and social work methods and of the hegemonic, monocultural atmosphere within social services.

\section{Struggles that arose during the changes}

While the Report had positive implications for Mäori social work and whänau, the implementation of the Report into policy and practice was not without its issues. Participants said that at the time, some social workers felt threatened by the changes that occurred within social service organisations. A few social workers, Mäori and non-Mäori, resisted the changes and for whatever reasons, disagreed with them. They said that many colleagues accepted and embraced the changes, or at least some changes, while others chose to 'push back', to maintain a monocultural stance; and others chose to leave the social work profession.

Another issue with the implementation of Püao-te- $\ddot{A}$ ta-tü was that while the document was well loved and supported, the recommendations were never fully implemented. Participants questioned the approaches that some organisations undertook to include Mäori methods into the organisational environment. They stated that some Mäori practices such 
as the use of Te Reo Mäori were accepted but the way it was implemented did not always benefit the whänau: 'They think they are doing Mäori a favour by putting [Mäori] names on everything. They are not doing us a favour'. The participants followed on to state that a more useful way to implement the Reo was when organisations encouraged all staff to practise and master the pronunciation of Mäori names.

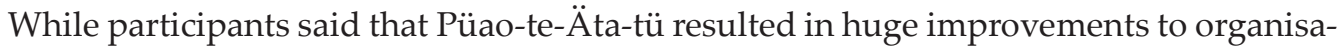
tions through introducing the powhiri process, it was problematic in some cases. Tikanga conflicts arose between Mäori and Päkehä processes, where Mäori staff were called upon to implement the process but for one reason or another it clashed with the norms of the non-Mäori members of the organisation. Other issues arose as well between staff from different iwi groups and those with limited or variable levels of knowledge on tikanga. One participant said that it became like 'dial a pöwhiri' where organisations, in some circumstances, lost the true purpose of the powhiri and were using the process too often, for the wrong reasons. This resulted in overworked Mäori staff and a sense that the pöwhiri was undervalued and overused.

There was a general sense that Mäori social workers are still waiting for the Govern-

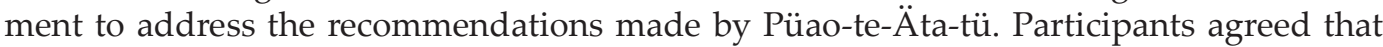
the Government still has a long way to go to achieve what was intended by Püao-te- $\ddot{A}$ ta-tü. They stated that they were still supportive of the implementation of Püao-te- $\ddot{t}$ ta-tü and felt less inclined to align themselves with more recent documents such as the Te Punga Report (1994) and later legislation. In order for the Government to fully commit to meeting the

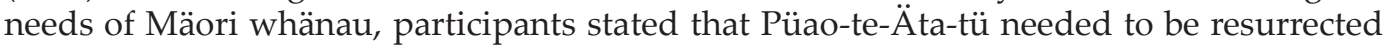
and maintained. In order to ensure its maintenance, social workers need to keep being taught about the values that underpin the Report so that they continue to advocate for its acknowledgement. Participants agreed that the education of young social workers was vital so that the passion for Püao-te-Äta-tü can be passed down through generations who may not have been around in the 1980s.

\section{Conclusions}

This research highlighted a number of key points, all of which emphasise the importance of the Püao-te-Äta-tü Report for Mäori social work practice and the betterment of Mäori whänau lives. The findings presented in this article reflect the körero from eight Mäori social workers, all with extensive social work experience. They comment first on what their Mäori social work methods are, then reflected upon the influences of the Püao-te- $\ddot{\text { ta}}$-tü Report on these methods, as well as other key influential factors. Mäori social work practices are underpinned by tikanga and it is the use of tikanga practices that most effectively empower Mäori whänau. While the Püao-te-Äta-tü Report made significant changes to social services, Mäori methods remained the same, grounded in tikanga, although these methods were validated, supported to a limited extent and sought out within organisations. They then described the influence of the Püao-te- $\ddot{\text { ta}}$-tü Report on social service organisations in general. It was found that the Püao-te- ̈̈ta-tü Report made fundamental changes to many aspects of social services: policy, procedures and attitudes. Mäori social workers note that the implementation of the Püao-te-Äta-tü Report was insufficiently done but that it set a benchmark for where social services should aim. While this is merely a brief description of their views, they reflect a depth of experience in the social services before, during and after 
the Report of 1986. Many conclusions can be drawn from their comments, but what has stood out is that the Püao-te-Äta-tü Report is a report of the people, belonging to Mäori social workers and, they hope, will not be forgotten.

\section{References}

Bevan-Brown, J. (1998). By Mäori, for Mäori, about Mäori - Is that enough? Palmerston North: Massey University. Bishop, R. (1996). Collaborative research stories. Whakawhanaungatanga. Palmerston North: The Dunmore Press.

Bruner, J. (1990) Acts of meaning. Cambridge: Harvard University Press.

Crotty, M. (1998). The foundations of social research: Meaning and perspective in the research process. Sydney: Allen and Unwin.

Eketone, A. (2008). Theoretical underpinnings of Kaupapa Mäori directed practice. Mai Review, 1, 1-11.

Glover, M. (2002). A literature review and commentary on the use of a kaupapa Mäori approach within a doctoral study of Mäori smoking cessation. Auckland: University of Auckland.

Hakiaha, M. (1997). Resolving conflict from a Mäori perspective. Te Komako: Social Work Review, 8.1.

Hemara, W. (2000). Mäori pedagogies: A view from the literature, pp. 1-12. NZCER display: Hamilton.

Hollis (2006). Püao-te-Äta-tü and Mäori social work methods. Unpublished masters thesis. Dunedin: University of Otago.

Huitt, W. (2003). 'Constructivism'. Educational psychology interactive. Valdosta: Valdosta State University. Available: http://chiron.valdosta.edu. Updated August 122005.

Keenan, D. (1995) Püao-te- Äta-tü: A brief history and reflection. Te Komako: Social Work Review, 7.1, 11-29.

Kiro, C. (2000). Mäori research and the social services: Te Puawaitanga o Te Tohu. Te Komako, Social Work Review, $7.4,26-32$.

Mahoney, M. (2004). What is constructivism and why is it growing? Contemporary Psychology, 49, 360-363.

Ministerial Advisory Committee on a Mäori Perspective for the Department of Social Welfare. (1986). Püao-te- Ätatü = Day Break: the report of the Ministerial Advisory Committee on a Mäori Perspective for the Department of Social Welfare. Wellington: New Zealand Department of Social Welfare.

Pitama, S. (2003) The skill of cutting harakeke: A literature review looking at best practice models/programmes that raise expectations of whanau, schools and communities for the success of Mäori youth and children, (pp. 1-41). Trans. Wellington: Te Puni Kokiri.

Ruwhiu, L. (2001). Bicultural issues in Aotearoa New Zealand social work. In M. Connolly (Ed.). New Zealand social work. Auckland: Oxford University Press.

Smith, L. T. (1999). Decolonising methodologies. Research and indigenous peoples. Dunedin: University of Otago Press.

Smith, G. H. (2003). Kaupapa Mäori theory: Theorising indigenous transforming of education E schooling, pp. 1-17. Hyatt Hotel, Auckland, New Zealand: The University of Auckland and Te Whare Wananga o Awanuiarangi: tribal-University; New Zealand.

The Department of Social Welfare. (1994). Te Punga: Our bicultural strategy for the nineties. Wellington: Ministry of Social Welfare.

Walker, H. (1995). Where is Püao-te-Äta-tü and the Department of Social Welfare? Te Komako: Social Work Review, 7.1, 12-16.

Walker, P. (2004). Partnership models within a Mäori social service provider. International Journal of Social Welfare, 13(2), 158-169..

Walker, S., Eketone, A., \& Gibbs, A. (2005). Research by Mäori, for Mäori: An exploration of kaupapa Mäori research, its principles and processes. Unpublished. Dunedin: University of Otago.

Walsh-Tapiata. (2003). A model for Mäori research. In Making a difference in families: Research that creates change, pp. 55-73. R. \& S. Monford (Eds). New South Wales: Allen and Unwin. 